\title{
Evaluation of Alternate, Fixed and Conventional Furrow Irrigation Systems with Different Water Application Level on Onion Yield in Dubti, Afar, Ethiopia
}

\author{
Zinabu Akele \\ Department of Irrigation and Drainage, Afar Pastoral and Agro pastoral Research Institute, Ethiopia
}

\begin{abstract}
Water scarcity is a major constraint for the production of food in arid and semi-arid areas. Therefore, deficit irrigation and application of irrigation systems are important concerns to improve water use efficiency without significant yield loss. The objective of an experiment was evaluating the performance of furrow irrigation systems under different water application levels on onion yield. The treatments were three deficit irrigation levels of $50 \%$, $75 \%$ and $100 \%$ of $\mathrm{ET}_{\mathrm{C}}$ with three furrow irrigation systems and laid out a factorial RCB design with three replications. The highest bulb yield and water use efficiency were obtained from CFI $100 \%$ and AFI $100 \%$ respectively. Bulb yield of CFI 100\%, CFI 75\%, and AFI 100\% were not shown a significant difference which is 25.46 ton/ha, 24.88 ton $/ \mathrm{ha}$, and 24.54 ton/ha respectively, besides better water use efficiency of $8.39 \mathrm{~kg} / \mathrm{m}^{3}$ was recorded from AFI $100 \%$. In relative to the control, AFI $100 \%$ able to increase 0.868 ha net additional irrigable land per each hectare. Therefore, it can be decided that Alternative furrow irrigation with $100 \% \mathrm{ET}_{\mathrm{C}}$ increased water use efficiency and can solve a problem of water shortage.
\end{abstract}

Keywords: Alternate Furrow; Crop Water Requirement; Deficit Irrigation; Onion; Water Use Efficiency

DOI: $10.7176 /$ IEL/9-5-03

Publication date:June $30^{\text {th }} 2019$

\section{INTRODUCTION}

Land and water scarcity are major constraints for the production of food required to satisfy the quantitative and qualitative shifts of the world's demand in the mid-twenty-first century. Moreover, the effect of a global climatic change is worsening the scarcity of water for irrigation (Behera and Panda, 2009). Irrigation accounts for more than $70 \%$ of the total water of the water withdrawn and for more than $90 \%$ of total consumptive use (Doll, 2009). These days, the tension between supply and demand for scarce water resource is aggravated owing to competition among agricultural, domestic and industrial water supply sectors (Perry et al., 2009). The possibility for further irrigation development to meet food demand in the future is constrained by decreasing water resources availability and growing competition for clean water (Kirda, 2002). The great challenge for the coming decades will therefore be the task of increasing food production per unit of water consumption, particularly in countries with limited water and land resources as well as inefficient water use. (Kirda, 2002) Increasing optimum water productivity, especially the value produced per unit of water, can be an important pathway for poverty alleviation (Perry et al., 2009). For a country like Ethiopia that follows Agricultural Development Lead Industrialization (ADLI), there is no readily identifiable yield increasing technology other than improved seed-water-fertilizer approach. Irrigation will, therefore, play an increasingly important role now and in the future both to increase the yield from already cultivated land and to permit the cultivation of what is today called marginal or unusable land due to moisture deficiency. Therefore, as they reported mechanisms which increase the water productivity of the irrigation scheme should be introduced. Improvement of irrigation water management is portrayed as the key issue in copping up with crop irrigation needs and future water scarcity. One of the irrigation management practices which could result in water saving is through deficit irrigation (Eck et al., 1987). One more option to increase water productivity through deficit level is alternate and fixed furrow irrigation system. The studies of Du et.al, (2010) improved by converting conventional furrow irrigation to alternate furrow irrigation (AFI) in order to increase water use efficiencies. In the lower Awash valley, which is located in the Afar region, there is suitable land for surface irrigation to produce lowland crops and legumes. Onion is a major crop next to maize in the area. However, water is the most limiting factor. The amount and distribution of rainfall are not sufficient to sustain crop growth and development in the study region. For this reason, river and groundwater are used as a source of irrigation water. Society desires to irrigate extra lands under limited water resource. Therefore, in the arid and semi-arid area application of deficit irrigation could provide greater economic returns than maximizing yields per unit of water. The deficit irrigation could be considered as a way of maximizing water use efficiency (WUE) by applying a reduced amount of irrigation water, which has no significant impact on yield. Yet, there is a lack of studies about the application of deficit irrigation and the performance of irrigation systems in the study region. Hence, this study aimed to investigate the performance of alternate furrow irrigation, fixed furrow irrigation and conventional furrow irrigation system on onion yield in the Lower Awash valley. 


\section{MATERIAL AND METHODS}

\subsection{Description of the study area}

The study was conducted at Dubti, Afar regional state located in the northeastern part of the Ethiopian Rift Valley at the lower portion of the Awash basin. The study area is to be found about $600 \mathrm{~km}$ northeast of Addis Ababa (capital city of Ethiopia) and $10 \mathrm{~km}$ from Samara, the capital city of Afar. Geographically, it is located between $11^{\circ} 20^{\prime}-12^{\circ} 25^{\prime} \mathrm{N}$ Latitudes and $40^{\circ} 06^{\prime}-41^{\circ} 30^{\prime} \mathrm{E}$ longitudes with an altitude that ranges from $339-381 \mathrm{~m}$. a. s. 1 . and its slope ranges between $0.03-0.3 \%$. Average annual rainfall is $222 \mathrm{~mm}$, which rated as low (Kibebew and Sileshi, 2016).

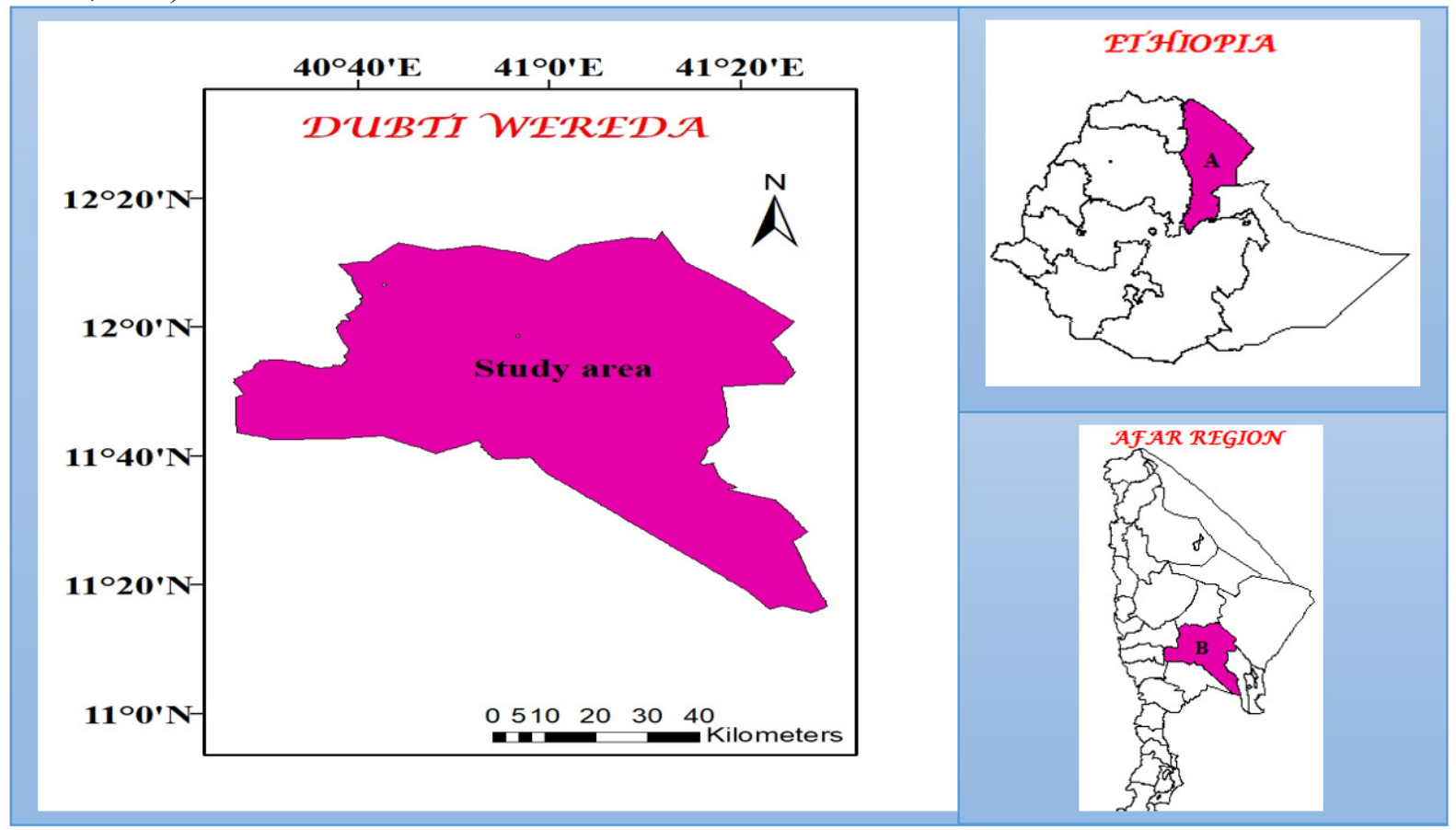

Figure 1: Location map of the study area

The Afar region in Ethiopia (A); Dubti wereda in Afar region (B); Dubti wereda (study area)

\subsection{Determination of reference evapotranspiration}

Based on daily meteorological data, the daily reference evapotranspiration $\left(\mathrm{ET}_{\mathrm{O}}\right)$ was determined by applying the modified FAO Penman-Monteith equation (Allen et al., 1998) with the help of CROPWAT software 8.0.

\subsection{Crop Water Requirement and Irrigation Scheduling}

Based on length of growing season, daily reference evapotranspiration and $\mathrm{K}_{\mathrm{c}}$-values at different crop stages daily ET $_{\mathrm{C}}$ was estimated from the expression of Allen et al., (1998):

$E T_{C}=K_{c} * E T_{o}$

where, $E T_{C}=$ crop water requirement (mm per day) and $K_{C}$ is infraction which is an empirical ratio of actual crop water use to reference evapotranspiration. The $\mathrm{K}_{\mathrm{c}}$ values obtained from reference texts of (Allen et al., 1998). Irrigation requirement values were obtained during the computation of $\mathrm{ET}_{\mathrm{C}}$ and effective rainfall. In this study, optimal irrigation schedule was analyzed using allowable soil moisture depletion. Optimal irrigation scheduling for no yield reduction is the irrigation given at $100 \%$ readily available soil moisture depletion to refill the soil to its field capacity.

$I R=E T_{C^{-}} P_{\text {eff }}$

where, $I R=$ Irrigation requirement $(\mathrm{mm}), P_{e f f}=$ Effective rainfall $(\mathrm{mm})$. The effective rainfall $\left(\mathrm{P}_{\text {eff }}\right)$ was estimated using the method of dependable formula. A 2-inch standard Parshal flume was set near the up-stream furrows, to monitor the rate of inflowing irrigation water.

The experimental treatments were:

\section{Treatment}

\section{$T_{1}$}

$\mathbf{T}_{2}$

$\mathrm{T}_{3}$

$\mathbf{T}_{4}$

$\mathbf{T}_{5}$

\section{Combinations}

Conventional Furrow Irrigation at $100 \% \mathrm{ET}_{\mathrm{C}}$ Conventional Furrow Irrigation at $75 \% \mathrm{ET}_{\mathrm{C}}$ Conventional Furrow Irrigation at $50 \% \mathrm{ET}_{\mathrm{C}}$ Alternative Furrow Irrigation at $100 \% \mathrm{ET}_{\mathrm{C}}$ Alternative Furrow Irrigation at $75 \% \mathrm{ET}_{\mathrm{C}}$
CFI $100 \%$

CFI $75 \%$

CFI $50 \%$

AFI $100 \%$

AFI $75 \%$ 
$T_{6}$

$\mathbf{T}_{7}$

$\mathbf{T}_{8}$

$T_{9}$
Alternative Furrow Irrigation at $50 \% \mathrm{ET}_{\mathrm{C}}$ Fixed Furrow Irrigation at $100 \% \mathrm{ET}_{\mathrm{C}}$

Fixed Furrow Irrigation at $75 \% \mathrm{ET}_{\mathrm{C}}$

Fixed Furrow Irrigation at $50 \% \mathrm{ET}_{\mathrm{C}}$
AFI $50 \%$

FFI $100 \%$

FFI $75 \%$

FFI $50 \%$

\subsection{Crop agronomy}

Onion Bombe red having a growing period of 145 days, was planted in the nursery and transplanted to the experimental plot after 45 days. Each experimental plot was $4 \mathrm{~m} * 2.8 \mathrm{~m}$ with $2 \mathrm{~m}$ free space between plots and a $3 \mathrm{~m}$ wide road between replications. The spacing between ridges, rows, and plants was $40 \mathrm{~cm}, 20 \mathrm{~cm}$, and $10 \mathrm{~cm}$ respectively with a double row. Each plot has six ridges and seven ends blocked furrows and having 40 plants in each row with a total plant population of (560) in each plot.

\subsection{Experimental design}

Each treatment was replicated three times and the plots have lied following a Factorial Randomized Complete lock Design (RCBD). Hence, the design was two factors factorial experiment $\left(3^{2}\right)$. CFI $100 \%$ was the control treatment. Five random plants per plot excluding the border rows and border plants in the central four rows were taken as a sample to record plant height, bulb diameter, and average weight. The number of total bulb and marketable yields was weighed from the four central rows of each plot to avoid border effects. Water use efficiency was determined by dividing the bulb yield produced from each treatment to the amount of water applied.

The computations and all statistical analyses were analyzed using the Statistics 10 statistical software. Mean separation was carried out using least significance difference (LSD) test at 5\% probability level.

\section{RESULTS}

Relative percentage of sand, silt, and clay were $10.67 \%, 53.83 \%$, and $35.50 \%$, respectively, according to the USDA soil textural classification, the percent particle size determination for the experimental site was revealed that Silty clay loam soil. Total available water of the experimental site soil was found to be $126.83 \mathrm{~mm}$ per meter depth. Onion root depth extends only to $60 \mathrm{~cm}$ and hence the TAW of onion is $73.5 \mathrm{~mm}$. (Table 1).

Table 1: Field capacity, Permanent wilting point and Bulk density of the experimental area

\begin{tabular}{lllll}
\hline Soil depth $(\mathbf{c m})$ & Bulk density $\left(\mathbf{g m} / \mathbf{c m}^{\mathbf{3}}\right)$ & $\begin{array}{l}\text { FC } \\
(\mathbf{\%})\end{array}$ & $\begin{array}{l}\text { PWP } \\
(\mathbf{\%})\end{array}$ & $\begin{array}{l}\text { TAW(mm } \\
\text { (m) }\end{array}$ \\
\hline $\mathbf{0 - 1 5}$ & 1.25 & 17.33 & 8.00 & 14.00 \\
$\mathbf{1 5 - 3 0}$ & 1.31 & 19.33 & 9.00 & 15.50 \\
$\mathbf{3 0 - 6 0}$ & 1.33 & 25.67 & 11.00 & 44.00 \\
$\mathbf{6 0 - 1 0 0}$ & 1.45 & 22.33 & 9.00 & 53.33 \\
\hline \multicolumn{1}{c}{ Total } & $\mathbf{1 . 3 3}$ & $\mathbf{2 1 . 1 7}$ & $\mathbf{9 . 2 5}$ & $\mathbf{1 2 6 . 8 3}$ \\
\hline
\end{tabular}

\subsection{Irrigation Water Requirements of Onion}

The daily weather data during the growing period from February 2 to May 2, 2017 were collected from Dubti Meteorological Station. Based on $\mathrm{ET}_{\mathrm{O}}$ and $\mathrm{K}_{\mathrm{C}}$ value, the seasonal crop and irrigation water requirement were found to be $516.42 \mathrm{~mm}$ and $482.35 \mathrm{~mm}$, respectively, this amount needed for full irrigation level treatments (CFI 100\%) (Table 2). 
Table 2: Crop and irrigation water requirement of the control treatment (CFI 100\%)

\begin{tabular}{lccccc}
\hline $\begin{array}{c}\text { Irrigation } \\
\text { Day }\end{array}$ & $\begin{array}{c}\text { ETC } \\
\text { Mm }\end{array}$ & $\begin{array}{c}\text { Rain Fall } \\
\text { mm/period }\end{array}$ & $\begin{array}{c}\mathbf{P}_{\text {eff }} \\
\text { mm/period }\end{array}$ & $\begin{array}{c}\text { NIR } \\
\text { mm/period }\end{array}$ & $\begin{array}{c}\text { Gross IR } \\
\text { mm/period }\end{array}$ \\
\hline 5-Feb & 15.32 & & & 15.32 & 25.53 \\
8-Feb & 13.13 & & & 13.13 & 21.88 \\
11-Feb & 12.01 & 16.00 & 9.24 & & 0.00 \\
14-Feb & 12.38 & & & 15.15 & 25.25 \\
17-Feb & 12.31 & & & 12.31 & 20.52 \\
21-Feb & 16.02 & & & 16.02 & 26.70 \\
25-Feb & 16.11 & & 19.14 & 16.11 & 26.85 \\
1-Mar & 20.79 & 25.00 & & & 0.00 \\
5-Mar & 23.86 & & & 25.50 & 42.50 \\
9-Mar & 24.71 & & & 24.71 & 41.18 \\
13-Mar & 25.73 & 10.00 & 5.68 & 20.05 & 33.42 \\
17-Mar & 28.08 & & & 28.08 & 46.80 \\
22-Mar & 29.03 & & & 29.03 & 48.38 \\
27-Mar & 32.06 & & & 32.06 & 53.43 \\
1-Apr & 32.71 & & & 32.71 & 54.52 \\
6-Apr & 36.79 & & & 36.79 & 61.32 \\
11-Apr & 35.65 & & & 35.65 & 59.42 \\
17-Apr & 43.16 & & & 43.16 & 71.93 \\
24-Apr & 38.92 & & & 38.92 & 64.87 \\
2-May & 47.65 & & & 47.65 & 79.42 \\
\hline Total & $\mathbf{5 1 6 . 4 2}$ & $\mathbf{5 1}$ & $\mathbf{4 4 . 0 6}$ & & $\mathbf{8 0 3 . 9 2}$ \\
\hline
\end{tabular}

\subsection{Irrigation Effect on Bulb Yield and Yield Parameters}

Table 3: Effects of irrigation levels and irrigation system on plant height, bulb diameter and average bulb weight

\begin{tabular}{|c|c|c|c|c|c|c|c|c|c|}
\hline & \multicolumn{3}{|c|}{ Irrigation systems(IS) } & \multicolumn{3}{|c|}{ Irrigation levels(IL) } & \multirow{2}{*}{$\begin{array}{l}\text { Grand } \\
\text { Mean }\end{array}$} & \multirow{2}{*}{$\mathrm{CV}$} & \multirow{2}{*}{$P$} \\
\hline & CFI & AFI & FFI & $100 \%$ & $75 \%$ & $50 \%$ & & & \\
\hline Plant Height (cm) & $43.74 a$ & 43.32b & $42.84 c$ & $45.02 a$ & $43.15 b$ & $41.73 c$ & 43.3 & 0.91 & 0.00 \\
\hline Bulb Diameter $(\mathrm{cm})$ & $55.05 a$ & $52.56 b$ & $50.03 c$ & $54.09 \mathrm{a}$ & $52.78 b$ & $50.76 c$ & 52.54 & 2.13 & 0.00 \\
\hline $\begin{array}{l}\text { Average Bulb Weight } \\
\text { (gm) }\end{array}$ & $61.63 a$ & $59.47 b$ & $56.88 \mathrm{c}$ & $62.05 a$ & $\mathbf{5 9 . 5 7 b}$ & $56.36 \mathrm{c}$ & 59.33 & 1.14 & 0.00 \\
\hline
\end{tabular}

\subsubsection{Plant height}

Irrigation systems and irrigation levels were highly significantly different from each other in plant height at $(\alpha \leq$ 0.01 ). The highest and lowest plant height of $45.02 \mathrm{~cm}$ and $41.73 \mathrm{~cm}$ was recorded by $100 \%$ and $50 \%$ ETc of irrigation depth respectively. $50 \%$ of irrigation depth of water applied recorded the lowest plant height. 100\% ETc got $3.29 \mathrm{~cm}$, which was greater than plant heights recorded in treatments that received $50 \%$ of irrigation depth. The highest plant height was $43.74 \mathrm{~cm}$ recorded by conventional furrow irrigation systems. Subsequently alternative and fixed furrow irrigation systems having, $43.32 \mathrm{~cm}$ and $42.84 \mathrm{~cm}$ plant height, respectively. The results of this study are consistent with those of Payero et al. (2006) who found that water stress reduces crop height, which in turn affects yield. The finding of this study is also in agreement with those of Yemane et al. (2018), who reported that water deficit significantly reduced plant height. 
Table 4: Depth of Irrigation Water Application on the Experimental Treatments (mm)

\begin{tabular}{lcccccc}
\hline & CFI & CFI & CFI & AFI/FFI & AFI/FFI & AFI/FFI \\
DATE & $\mathbf{1 0 0 \%}$ & $\mathbf{7 5 \%}$ & $\mathbf{5 0 \%}$ & $\mathbf{1 0 0 \%}$ & $\mathbf{7 5 \%}$ & $\mathbf{5 0 \%}$ \\
\hline 5-Feb & 15.32 & 11.49 & 7.66 & 7.66 & 5.75 & 3.83 \\
8-Feb & 13.13 & 9.85 & 6.57 & 6.57 & 4.92 & 3.28 \\
11-Feb & 0.00 & 0.00 & 0.00 & 4.62 & 4.62 & 4.62 \\
14-Feb & 15.15 & 11.36 & 7.58 & 7.58 & 5.68 & 3.79 \\
17-Feb & 12.31 & 9.23 & 6.16 & 6.16 & 4.62 & 3.08 \\
21-Feb & 16.02 & 12.02 & 8.01 & 8.01 & 6.01 & 4.01 \\
25-Feb & 16.11 & 12.08 & 8.06 & 8.06 & 6.04 & 4.03 \\
1-Mar & 0.00 & 0.00 & 0.00 & 9.57 & 9.57 & 9.57 \\
5-Mar & 25.50 & 19.13 & 12.75 & 12.75 & 9.56 & 6.38 \\
9-Mar & 24.71 & 18.53 & 12.36 & 12.36 & 9.27 & 6.18 \\
13-Mar & 20.05 & 15.04 & 10.03 & 12.87 & 9.65 & 6.43 \\
17-Mar & 28.08 & 21.06 & 14.04 & 14.04 & 10.53 & 7.02 \\
22-Mar & 29.03 & 21.77 & 14.52 & 14.52 & 12.26 & 7.31 \\
27-Mar & 32.06 & 24.05 & 16.03 & 16.03 & 12.02 & 8.02 \\
1-Apr & 32.71 & 24.53 & 16.36 & 16.36 & 12.27 & 8.18 \\
6-Apr & 36.79 & 27.59 & 18.40 & 18.40 & 13.80 & 9.20 \\
11-Apr & 35.65 & 26.74 & 17.83 & 17.83 & 13.37 & 8.91 \\
17-Apr & 43.16 & 32.37 & 21.58 & 21.58 & 16.19 & 10.79 \\
24-Apr & 38.92 & 29.19 & 19.46 & 19.46 & 14.60 & 9.73 \\
2-May & 47.65 & 35.74 & 23.83 & 23.83 & 17.87 & 11.91 \\
\hline Total & $\mathbf{4 8 2 . 3 5}$ & $\mathbf{3 6 1 . 7 6}$ & $\mathbf{2 4 1 . 1 8}$ & $\mathbf{2 5 8 . 2 1}$ & $\mathbf{2 0 0 . 0 4}$ & $\mathbf{1 3 9 . 0 4}$ \\
\hline
\end{tabular}

\subsubsection{Bulb diameter}

Irrigation systems and irrigation levels have shown that there was a highly significant difference $(\alpha \leq 0.01)$ on bulb diameter. On this test, the irrigation systems show that the largest bulb diameter was recorded for CFI and AFI with the value of $55.05 \mathrm{~mm}$ and $52.56 \mathrm{~mm}$ respectively. However, the least bulb diameter $50.03 \mathrm{~mm}$ was recorded for fixed furrow irrigation. The irrigation level, largest onion bulbs were $54.09 \mathrm{~mm}$ diameter recorded from $100 \%$ $\mathrm{ET}_{\mathrm{C}}$ amount of irrigation water applied. On the other hand, the least bulb diameter $50.76 \mathrm{~mm}$ was recorded from irrigation level treated with 50\% irrigation depth. The result has in agreement with Enchalew et.al (2016) and Yemane, (2018) they reported bigger photosynthetic area of the plant like the height of plants and number of leaves were formed due to high irrigation levels, which increased the amount of assimilating partitioned to the bulbs and increased bulb diameter. Also, the result is in line to Olalla et al. (2004) reported that plots which received the maximum volumes of water yielded harvests with greater percentages of large size bulbs whereas limitation of water led to small-size bulbs. In addition, Biswas et al. (2003) indicated that the bulb diameter of onions was increased at a higher amount of irrigation. Similarly, this indicates that transpiration, photosynthesis and growth rates were lowered by water stress as a stressed plant produces smaller sized bulbs.

\subsubsection{Average bulb weight}

The average bulb weight per plant was shown significantly differenced by their interaction effects $(\alpha \leq 0.05)$. Moreover, the average bulb weight per plant of onion was a highly significant difference $(\alpha \leq 0.01)$ by the main effects of irrigation systems and irrigation levels. On this result, the highest average bulb weight $61.63 \mathrm{gm}$ was recorded from Convectional Furrow irrigation and Alternative Furrow irrigation was an average bulb size of 59.47 gm; whereas the lowest average bulb weight was recorded at Fixed Furrow irrigation with 56.88 gm weight. Decreasing applied water by $25 \%$ and $50 \%$ of ET $_{\mathrm{C}}$ led to decreased average bulb weight of onion by $4.00 \%$ and $9.17 \%$, respectively. The maximum value of the average bulb weigh per plant was recorded as 62.05 gm for $100 \%$ of irrigation level. While for $75 \%$ and $50 \%$ were obtained $59.57 \mathrm{gm}$ and $56.36 \mathrm{gm}$, respectively. The lowest average bulb weight per plant was obtained from the treatment of 50\% of irrigation level. Similarly, Subedi et al. (2002) reported that average bulb weight of onion was significantly increased at $120 \% \mathrm{ET}_{\mathrm{C}}$ irrigation levels. Average bulb weight of onion responded to an increased level of irrigation water applied. The increment in bulb weight due to increase in irrigation levels might be because the growth of taller plants is depicted by a higher number of leaves causing for better synthesis and transportation that assimilates from source to sinks (Biswas et al., 2003).

\subsubsection{Total bulb yield}

With the intention of comparing the yield performance of the three irrigation systems with irrigation levels. Onion bulb yield was collected from the four centered ridges of every plot $\left(4.8 \mathrm{~m}^{2}\right)$, and converted into hectare basis. The total bulb yields was shown highly significant difference $(\alpha \leq 0.01)$ on the interaction effect of irrigation systems and irrigation levels. The interaction effect, significantly higher bulb yield of $25.46 \mathrm{ton} / \mathrm{ha}, 24.88$ ton/ha, 24.54 ton/ha and 23.20 ton/ha, was recorded by CFI $100 \%$, CFI $75 \%$, AFI $100 \%$, and CFI $50 \%$, respectively. The CFI at full irrigation (100\%) gave 0.58 ton/ha greater than it produced in plots which received $75 \%$ and 0.92 ton/ha 
greater which received $100 \%$ irrigation level of AFI. The least bulb yield was recorded on FFI $50 \%$, followed by FFI 75\%, FFI 100\% and AFI 50\% which is 14.56 ton/ha, 16.75 ton/ha, 19.86 ton/ha and 21.56 ton/ha, respectively. However, the effects of AFI 100\%, CFI 75\%, and CFI 100\% have no significant difference in yield. Therefore, AFI $100 \%$ saves more water than full irrigation without significant loss of yield. Furrow irrigation systems and irrigation levels have shown highly significant differences $(\alpha \leq 0.01)$ effect. Higher total onion bulb yield was recorded when conventional furrow irrigation system was applied that gave 24.51 ton/ha and 22.96 ton/ha was recorded under alternative furrow irrigation. The lowest total bulb yield of $17.06 \mathrm{ton} / \mathrm{ha}$ was recorded at fixed furrow irrigation. Irrigation levels were shown a highly significant difference among irrigation level on total bulb yield $(\alpha \leq 0.01)$. The yield of onion decreased as the irrigation level decreased. The highest total bulb yield of $23.29 \mathrm{ton} /$ ha was recorded on irrigation level of $100 \% \mathrm{ET}_{\mathrm{C}}$ and followed by $21.42 \mathrm{ton} / \mathrm{ha}$, for $75 \% \mathrm{ET}_{\mathrm{C}}$. The lowest value of 19.81 ton/ha yield was observed in $50 \%$ of water applied. Decreasing applied water by $25 \%$, and $50 \%$ of ET $_{\mathrm{C}}$ led to decreased in bulb yield of onion by $8.03 \%$ and $14.95 \%$, respectively. Similarly, Kang et al (2000) evaluated the alternate furrow irrigation, fixed furrow irrigation and conventional furrow irrigation with different irrigation amounts for crop production. They reported that the reduction of crop yield in alternate furrow irrigation was not shown a significant difference, unlike fixed furrow irrigation. The rise in onion total bulb yield might be attributed to the large size of onion bulb due to an application of a high amount of irrigation. (Bekele, 2007).

Table 5: Interaction effects of furrow irrigation systems and irrigation levels on bulb yield (ton/ha)

\begin{tabular}{|c|c|c|c|c|}
\hline Group & $100 \%$ & $75 \%$ & $50 \%$ & Mean \\
\hline CFI & $25.46 a$ & $24.88 \mathrm{a}$ & $23.20 \mathrm{~b}$ & $24.51 a$ \\
\hline AFI & $24.54 \mathrm{a}$ & $22.64 b c$ & $21.69 \mathrm{c}$ & $22.96 b$ \\
\hline FFI & $19.86 \mathrm{~d}$ & $16.75 \mathrm{e}$ & $14.56 \mathrm{f}$ & $17.06 \mathrm{c}$ \\
\hline Mean & $23.29 a$ & $21.42 b$ & 19.81c & \\
\hline Grand mean & 25.51 & & & \\
\hline $\mathrm{CV}$ & 3.18 & & & \\
\hline $\mathbf{P}$ & 0.009 & & & \\
\hline
\end{tabular}

\subsubsection{Marketable yield}

The interaction effect of furrow irrigation systems and irrigation levels were shown highly significant differences $(\alpha \leq 0.01)$ on the marketable bulb yield of onion. Similarly, Marketable bulb yield of onion was shown highly significantly affected $(\alpha \leq 0.01)$ by the furrow irrigation systems and irrigation levels. Conventional furrow irrigation systems gave more Marketable yield with irrigation water amount of $100 \%$ (full irrigation) followed by AFI $100 \%$ and CFI 75\% which is 25.42 ton/ha, 22.51 ton/ha and 21.20 ton/ha, respectively. The least marketable yield was scored in FFI 50\% and AFI 50\% with 12.94 ton/ha and 14.50 ton/ha, respectively. Yet, CFI with $100 \%$ gave optimum yield followed by AFI with $100 \%$. The increment in marketable bulb yield due to an application of irrigation water could be attributed to the increment in vegetative growth and total bulb yield, which is associated with an increment in bulb diameter and average bulb weight (Neeraja et al., 1999).

3.2.5. Water use efficiency (WUE)

Table 6: Interaction Effects of irrigation systems and irrigation levels on water use efficiency $\left(\mathrm{kg} / \mathrm{m}^{3}\right)$

\begin{tabular}{|c|c|c|c|c|}
\hline Group & $100 \%$ & $75 \%$ & $50 \%$ & Mean \\
\hline CFI & $4.930 \mathrm{~g}$ & $6.423 \mathrm{f}$ & $8.984 c$ & $6.779 \mathrm{c}$ \\
\hline AFI & $8.396 \mathrm{~d}$ & $10.330 \mathrm{~b}$ & $14.840 \mathrm{a}$ & 11.189a \\
\hline FFI & $6.795 f$ & $7.641 \mathrm{e}$ & $9.963 b$ & 8.133b \\
\hline Mean & $6.707 \mathrm{c}$ & 8.131b & $11.262 \mathrm{a}$ & \\
\hline Grand mean & 8.70 & & & \\
\hline $\mathrm{CV}$ & 3.36 & & & \\
\hline $\mathbf{P}$ & 0.00 & & & \\
\hline
\end{tabular}

Irrigation levels and furrow irrigation systems were highly significant $(\alpha \leq 0.01)$ on crop water use efficiency of onion. In addition, their interaction effect was shown a highly significant difference $(\alpha \leq 0.01)$ on water use efficiency. Significantly higher water use efficiencies were $14.84 \mathrm{~kg} / \mathrm{m}^{3}, 10.33 \mathrm{~kg} / \mathrm{m}^{3}, 9.96 \mathrm{~kg} / \mathrm{m}^{3}$ and $8.99 \mathrm{~kg} / \mathrm{m}^{3}$ were recorded by AFI 50\%, AFI 75\%, FFI 50\%, and CFI 50\%, respectively. The least water use efficiencies were recorded on CFI $100 \%$, followed by CFI $75 \%$, FFI $100 \%$ and FFI $75 \%$ which is $4.93 \mathrm{~kg} / \mathrm{m}^{3}, 6.42 \mathrm{~kg} / \mathrm{m}^{3}, 6.79$ $\mathrm{kg} / \mathrm{m}^{3}$ and $7.64 \mathrm{~kg} / \mathrm{m}^{3}$, respectively. Irrigation systems as the main effect influenced water use efficiency. WUE values with the furrow irrigation systems recorded $6.77 \mathrm{~kg} / \mathrm{m}^{3}$ for conventional furrow irrigation and while AFI and FFI had higher values of $11.19 \mathrm{~kg} / \mathrm{m}^{3}$ and $8.13 \mathrm{~kg} / \mathrm{m}^{3}$, respectively. The highest WUE was recorded from alternate furrow irrigation. Irrigation levels, as main effect, increased WUE $(\alpha<0.01)$ to a higher value of 11.26 $\mathrm{kg} / \mathrm{m}^{3}$ with $50 \%$ whereas $75 \%$ and $100 \%$ irrigation levels got $8.13 \mathrm{~kg} / \mathrm{m}^{3}$ and $6.71 \mathrm{~kg} / \mathrm{m}^{3}$, respectively. In line with this result, Samson and Ketema (2007) reported that deficit irrigations increased the water use efficiency of onion than full irrigation. Alternate furrow irrigation also increased water use efficiency in a wheat-cotton rotation in Punjab, India Yazar et al (2009). Furthermore, use of the alternate furrow irrigation increased water use efficiency 
rather than conventional furrow irrigation in sugarcane fields in southern part of Iran.

Net additional irrigable area due to water saved from irrigation methods and application levels of onion production estimated according to water applied for each treatment. As indicated in Table 7, the result showed that the minimum yield reduction was from AFI $100 \% \mathrm{ET}_{\mathrm{C}}$ correspondingly saves $46.47 \%$ water from the required amount of net irrigation for one hectare. Accordingly, 0.868 ha area able to irrigate additionally per each hectare. $\mathrm{CFI}$ with $100 \% \mathrm{ET}_{\mathrm{C}}$ was used as a control for all treatment. It clearly seen that the value of net yield generated was not influenced only by water applied but also furrow irrigation methods.

Table 7: Extent of saved water and yield reduction

\begin{tabular}{lccccc}
\hline $\begin{array}{c}\text { Treatme } \\
\text { nt }\end{array}$ & $\begin{array}{c}\text { Marketa } \\
\text { ble } \\
\text { (ton/ha) }\end{array}$ & $\begin{array}{c}\text { Yield } \\
\text { Reduction } \\
(\%)\end{array}$ & $\begin{array}{c}\text { NIrr } \\
\left(\mathbf{m}^{\mathbf{3}} / \mathbf{h a}\right)\end{array}$ & $\begin{array}{c}\text { Water saved from NIrr } \\
\left(\mathbf{m}^{\mathbf{3}} / \mathbf{h a}\right)\end{array}$ & $\begin{array}{c}\text { Water saved from } \\
\text { NIrr } \mathbf{( \% )}\end{array}$ \\
\hline $\begin{array}{l}\text { CFI100 } \\
\text { \% }\end{array}$ & 25.42 & $0.00 \%$ & 482.35 & 0.00 & $0.00 \%$ \\
CFI75\% & 21.20 & $16.60 \%$ & 361.76 & 120.59 & \\
CFI50\% & 16.45 & $35.29 \%$ & 241.18 & 241.17 & $25.00 \%$ \\
AFI100 & 22.51 & $11.45 \%$ & 258.21 & 224.14 & $50.00 \%$ \\
\% & & & & & $46.47 \%$ \\
AFI75\% & 20.31 & $20.10 \%$ & 200.04 & 282.31 & $58.53 \%$ \\
AFI50\% & 14.50 & $42.96 \%$ & 139.04 & 343.31 & $71.17 \%$ \\
FFI100 & 19.00 & $25.26 \%$ & 258.21 & 224.14 & $46.47 \%$ \\
\% & & & & & \\
FFI75\% & 15.70 & $38.24 \%$ & 200.04 & 282.31 & $58.53 \%$ \\
FFI50\% & 12.94 & $49.10 \%$ & 139.04 & 343.31 & $71.17 \%$ \\
\hline
\end{tabular}

\section{CONCLUSION}

Irrigation systems and irrigation levels have shown a highly significant difference in plant height, bulb diameter, average bulb weight, total bulb yield, and water use efficiency. The interaction effect of irrigation systems and irrigation levels was shown significantly different on average bulb weight and highly significant difference on total bulb yield, and water use efficiency. However, the interaction effect of irrigation systems and irrigation levels was not shown significantly different on plant height, and bulb diameter. Results obtained from this study was shown that the AFI $100 \%$ system lead to lesser water input and yet was still able to generate comparable onion yield with CFI 100\% and CFI 75\%. Relative to the control of CFI 100\% the lowest marketable yield percentage of $11.45 \%$ was recorded in AFI 100\%. Moreover, applying AFI 100\%, net area of 0.868 ha will be able to irrigate additionally to per each hectare. Using AFI $100 \%$, which may result in significant benefits under limited water condition, labor saving and enhanced flexibility in farm irrigation management.

\section{REFERENCES}

Allen, R.G., L.S. Pereira, D. Raes and M. Smith, 1998. Crop Evapotranspiration Guidelines for Calculating Crop Water Requirements. FAO, 56 Rome, Italy.

Behera, S.K. and R.K. Panda, 2009. Integrated management of irrigation water and fertilizer for wheat crop using field experiment and simulation modeling: Agricultural water Management 96: pp. 1532-1540.

Biswas, S.K., P.K. Sarker, A. K. M, Mazharulislam, M.A. Bhuyan and B.C. Kundu. 2003. Effect of irrigation on onion production. Pakistan Journal Biology Science, 6(20): 1725-1728.

Doll, P., 2009. Vulnerability to the impact of climate change on renewable groundwater resources: a global-scale assessment.

Du, T. S., Kang, S. Z., Sun, J. S., Zhang, X. Y., Zhang, J. H., 2010. An improved water use efficiency of cereals under temporal and spatial deficit irrigation in north China. Agric. Water Manag. 97 (1), 66-74.

Eck, H.V., A.C. Mathers, and J.T. Musick., 1987. Plant water stress at various growth stages, growth, and yield of soybean. Field Crop Research, 17: pp. 1-16.

Enchalew B, Gebre SL, Rabo M, Hindaye B, Kedir M, et al. (2016) Effect of Deficit Irrigation on Water Productivity of Onion (Allium cepal.) under Drip Irrigation. Irrigation Drainage Sys Eng 5:172. doi: 10.4172/2168- 9768.1000172

Kang S., Z. Liang, Pan, Y. and. Zhang, J. 2000. Alternate furrow irrigation for maize production in an arid area. Agricultural Water Management 45: pp. 267-274

Kibebew, K., \& Sileshi, A. A. (2016). "Status of Salt Affected Soils, Irrigation Water Quality and Land suitability of Dubti/Tendaho Area, North Eastern Ethiopia (Doctoral dissertation, Haramaya University)

Kirda, C. (2002). Deficit irrigation scheduling based on plant growth stages showing water stress tolerance. Food and Agricultural Organization of the United Nations, Deficit Irrigation Practices, Water Reports, 22, 102.

Mansouri-Far, Cyrus, Seyed Ali Mohammad Modarres Sanavy, and Seyed Farhad Saberali. "Maize yield response 
to deficit irrigation during low-sensitive growth stages and nitrogen rate under semi-arid climatic conditions." Agricultural Water Management 97.1 (2010): 12-22.

Neeraja, G., et al. "Effect of irrigation and nitrogen on growth yield and yield attributes of Rabi onion (Allium cepa) in Andhra Pradesh." Veg. Sci 26.1 (1999): 64-68.

Olalla, F.S., A. D. Padilla and R. Lopez. 2004. Production and quality of the onion crop (Allium cepa L.) Cultivated under controlled deficit irrigation conditions in a semi-arid climate. Agricultural Water Management, 68: 77-89.

Payero, J.O., S.R. Melvin, S. Irmak and D. Tarkalson, 2006. Yield response of corn to deficit irrigation in a semiarid climate. Agri. Water Manage. 84: 101-112.

Perry, C., P. Steduto, R.A. Allen and C.M. Burt, 2009. Increasing productivity in irrigated Agriculture: Agronomic constraints and hydrological realities. Agricultural water Management 96: pp.1517-1524.

Samson Bekele, and Ketema Tilahun. "Regulated deficit irrigation scheduling of onion in a semiarid region of Ethiopia." Agricultural Water Management 89.1-2 (2007): 148-152.

Subedi, D., Gautam, D., Shakya, S., \& Srivastava, A. (2002). Effect of Irrigation on Production of Onion Bulb. Journal of the Institute of Agriculture and Animal Science, 23, 35-40.

Yazar A, Gokle F and Sezen M.S 2009. Corn yield response to partial root zone drying and deficit irrigation strategies applied with drip system. Plant soil Environ, 55, 2009 (11) $494-503$

Yemane M., Abraham W., And Solomon H., 2018. Response of onion (Allium cepa 1.) to deficit irrigation under different furrow irrigation water management techniques in Raya Valley, Northern Ethiopia. African Journal of Plant Science. Vol. 12(5), pp. 105-113 